\title{
Dry Matter Accumulation of Four Warm Season Grasses in the Nebraska Sandhills
}

\author{
WILLIAM L. GILBERT, L.J. PERRY, JR., AND J. STUBBENDIECK
}

\begin{abstract}
Grass development and seasonal growth patterns are used in making range management decisions. Plant development and dry matter accumulation of four warm-season grasses were studied in the Nebraska Sandhills. Development of the grasses were slowed during 1974 due to low precipitation. Plant, leaf hlade, and stem dry matter accumulation per shoot increased with successive harvests and were considerably greater both years for the tall grasses, sand bluestem [Andropogon hallii Hack.] and switchgrass [Panicum virgatum L.], than for the mid-grasses, little bluestem [Schizachyrium scoparium (Michx.) Nash.] and sand lovegrass [Eragrostis trichodes (Nutt.) Wood]. Leaf blade to stem ratios decreased with successive harvests for all grasses. Dry matter accumulation of the tall grasses was affected more by the low rainfall in 1974 than that of the mid-grasses. At the last harvest, decrease in stem dry matter accumulation was considerably greater than the decrease in leaf blade dry matter accumulation in 1974 as compared to 1973 .
\end{abstract}

Knowledge of development and seasonal growth patterns of grasses is used in making management decisions for proper range use. Development of plants can be altered by many climatic and management factors.

Time and height of growing point elevation of grasses is important in determining the reaction of shoots to herbage removal. The growing point remains below the soil surface during early vegetative growth and is elevated later in the growing season with internode elongation. If the growing point is removed after elevation, normal shoot development is arrested, and any further growth can only come from axillary buds at the shoot base (Cook and Stoddart 1953; Rechenthin 1956; Booysen et al. 1963; Hyder 1972).

Dry matter accumulation in grasses results from the interaction of the genetic constitution of the plant and environmental factors. Available soil moisture is probably the most important environmental factor influencing growth and development of grasses. High correlations have been found between available soil moisture and forage production (Cable 1971; Shiflet and Dietz 1974). Temperature affects precipitation effectiveness, as higher temperatures are associated with greater evapotranspiration losses.

Dry matter accumulation of a plant, when plotted, is generally represented by a sigmoid curve. The sigmoid curve can be separated into three growth periods: (1) early period of slow growth, (2) middle period of rapid growth, and (3) final period

W. L. Gilbert, former graduate research assistant, is currently with Bureau of Land Management, Price, Utah 84501; L.J. Perry. Jr. (deceased) and J. Stubbendieck, were associate professors of Agronomy, University of Nebraska, Lincoln, at the time of the research.

This report is a contribution of the Nebraska Agricultural Experiment Station as Technical Paper Number 5328

Manuscript received May 15, 1977 of slow growth (Stubbendieck and Burzlaff 1971). Early above-ground growth is primarily leaf material. Stem material is added later as the shoot and inflorescence develop during the middle period of rapid growth. In the last phase, dry matter accumulation continues, but at a slower rate (Sims et al. 1971; Sims et al. 1973; Pieper et al. 1974).

Four abundant grasses found in the Nebraska Sandhills are little bluestem [Schizachyrium scoparium (Michx.) Nash.], sand bluestem [Andropogon hallii Hack.], and sand lovegrass [Eragrostis trichodes (Nutt.) Wood], and switchgrass [Panicum virgatum $L$.]. They are important for soil stability and forage production. All four grasses are native, warm season, perennials. Sand bluestem and switchgrass are rhizomatous tall grasses, while little bluestem and sand lovegrass are midgrasses and grow in bunches.

Objectives of this study were to examine stages of development and time of growing point elevation and to measure plant, leaf blade, and stem dry matter accumulation during two consecutive growing seasons.

\section{Materials and Methods}

The study was located in the Nebraska Sandhills near Halsey. The study area had a gently rolling topography and was classified as a sands range site. Range condition was excellent. Soil was a Valentine fine sand. Native tall and mid-grasses and forbs composed the dominant vegetation. No domestic livestock grazing had occurred since about 1935 . About $70 \%$ of the annual precipitation falls within the April through September growing season.

In March, 1973 and 1974, 110 plants each of little bluestem, sand bluestem, sand lovegrass, and switchgrass were selected randomly throughout a 5-ha area. Dry matter accumulation was determined by harvesting the plants at weekly intervals beginning June 4, 1973, and May 27, 1974, and continued for 11 consecutive weeks. Stage of development was recorded at each harvest. Growing point height was measured in $\mathrm{cm}$ from the soil surface to the top of the shoot apex. Different plants were harvested each week with a minimum of 10 shoots per plant randomly clipped to a $2.5 \mathrm{~cm}$ height. Harvested shoots were separated into leaf blades and remaining topgrowth, hereafter referred to as stems. Forage was oven-dried at $70^{\circ} \mathrm{C}$ until a constant weight was obtained.

The study was conducted in a completely randomized design with ten replications. A factorial arrangement was used. Factors were years, grasses, and harvests with 2, 4, and 11 levels, respectively. An analysis of variance was computed for each variable. The treatment sum of squares was partitioned into years, grasses, and harvests, and their interactions. Years were considered a random effect and grasses and harvests fixed effects. Duncan's multiple range test was used to compare treatment means.

\section{Results and Discussion}

Annual and growing season precipitation were considerably lower in 1974 than in 1973. Between April 1 and July 31, 


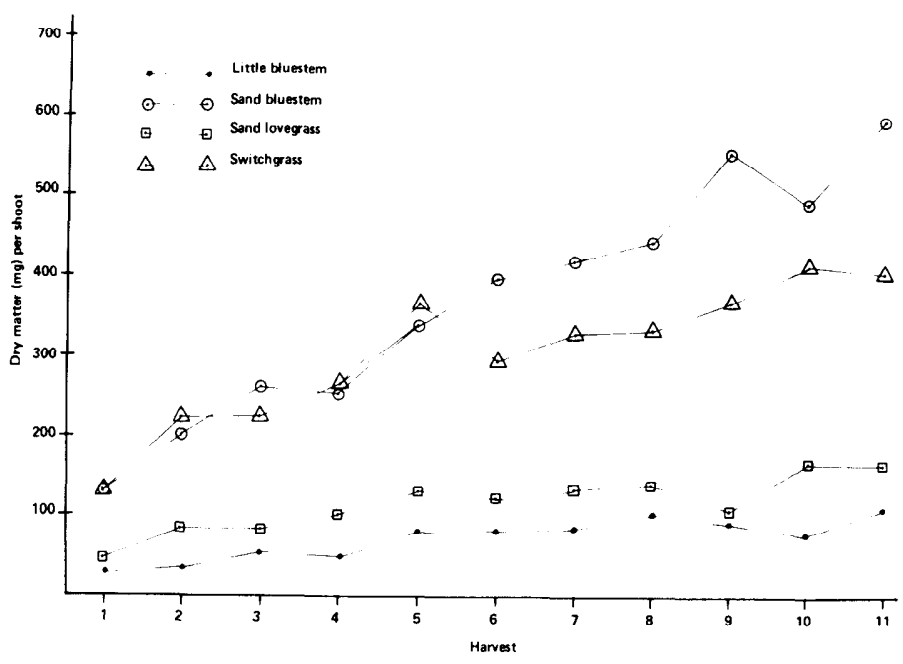

Fig. 4. Leaf blade dry matter accumulation of four warm-season grasses harvested at weekly intervals beginning May 27,1974, near Halsey, Nebr.

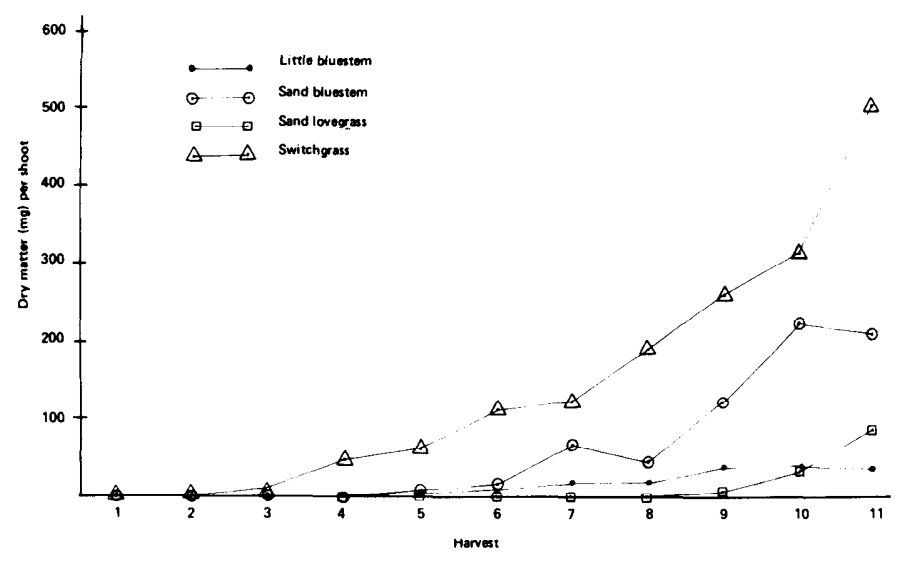

Fig. 5. Stem dry matter accumulation of four warm-season grasses harvested at weekly intervals beginning June 4, 1973, near Halsey, Nebr.

lowest for switchgrass, although few differences among the grasses were significant.

Both leaf blade and stem dry matter accumulation were significantly less at most harvests in 1974 than in 1973 for the tall grasses. At the last harvest, the decrease in stem dry matter accumulation, in 1974 as compared to 1973, was considerably greater than the decrease in leaf blade dry matter accumulation.

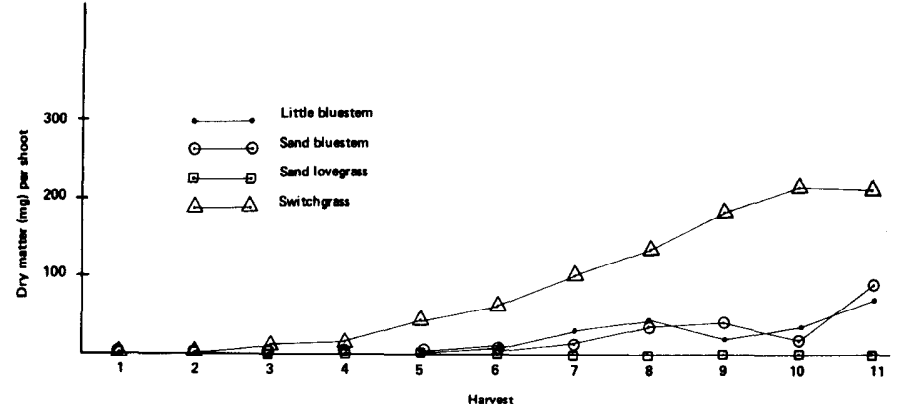

Fig. 6. Stem dry matter accumulation of four warm-season grasses har vested at weekly intervals beginning May 27,1974, near Halsey, Nebr.

Thus the decrease in plant dry matter accumulation at the last harvest in 1974 can be attributed mostly to the decrease in stem dry matter accumulation. The lower dry matter accumulation was associated with the low precipitation in July of 1974, which occurred at a time when considerable leaf growth had occurred and stem growth was just beginning.

\section{Literature Cited}

Booysen, P. de V., N.M. Tainton, and J.D. Scott. 1963. Shoot-apex development in grasses and its importance in grassland management. Herbage Abstr. 33:209-213.

Branson, F.A. 1953. Two new factors affecting resistance of grasses to grazing. J. Range Manage. 6:165-171.

Cable, D.R. 1971. Growth and development of Arizona cottontop [Trichachne californica (Benth.) Chase]. Bot. Gaz. 132:119-145.

Cook, C.W., and L.A. Stoddart. 1953. Some growth responses of crested wheatgrass following herbage removal. J. Range Manage. 6:267-270.

Hyder, D.N. 1972. Defoliation in relation to vegetative growth. p. 304-317. In: V.B. Youngner and C.M. McKell (eds.), The Biology and Utilization of Grasses. Academic Press, New York. 426 p.

Pieper, R.D., C.H. Herbel, D.D. Dwyer, and R.E. Banner. 1974. Management implications of herbage weight changes on native rangeland. J. Soil and Water Cons. 29:227-229.

Rechenthin, C.A. 1956. Elementary morphology of grass growth and how it affects utilization. J. Range Manage. 9:167-170.

Shiflet, T.N., and H.E. Dietz. 1974. Relationship between precipitation and annual rangeland herbage production in southeastern Kansas. J. Range Manage. 27:272-276.

Sims, P.L., L.J. Auyko, and D.N. Hyder. 1972. Developmental morphology of switchgrass and sideoats grama. J. Range Manage. 24:357-360.

Sims, P.L., R.K. Lang'at, and D.N. Hyder. 1973. Developmental morphology of blue grama and sand bluestem. J. Range Manage. 26:340-344.

Stubbendieck, J., and D.F. Burzlaff. 1971. Nature of phytomer growth in blue grama. J. Range Manage. 24:154-156. 